This article was downloaded by: [New York University]

On: 09 December 2014, At: 12:54

Publisher: Routledge

Informa Ltd Registered in England and Wales Registered Number: 1072954

Registered office: Mortimer House, 37-41 Mortimer Street, London W1T

3J H, UK

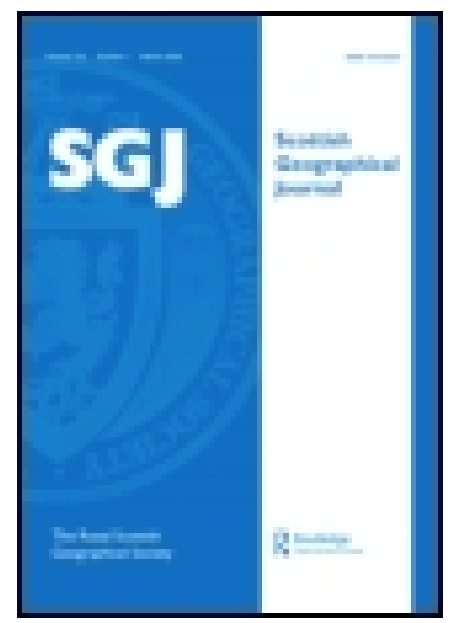

Scottish Geographical Magazine

Publication details, including instructions for authors and subscription information: http:// www.tandfonline.com/loi/ rsgj 19

\title{
Address to the geographical section of the British association, 1899
}

Sir J ohn Murray K.C.B., F.R.S., D.SC., LL.D. ${ }^{a}$

a President of the Section

Published online: 27 Feb 2008.

To cite this article: Sir J ohn Murray K.C.B., F.R.S., D.Sc. , LL.D. (1899) Address to the geographical section of the British association, 1899, Scottish Geographical Magazine, 15: 10, 505-522, DOI: 10.1080/00369229908733091

To link to this article: http:// dx. doi.org/ 10.1080/ 00369229908733091

\section{PLEASE SCROLL DOWN FOR ARTICLE}

Taylor \& Francis makes every effort to ensure the accuracy of all the information (the "Content") contained in the publications on our platform. However, Taylor \& Francis, our agents, and our licensors make no representations or warranties whatsoever as to the accuracy, completeness, or suitability for any purpose of the Content. Any opinions and views expressed in this publication are the opinions and views of the authors, and are not the views of or endorsed by Taylor \& Francis. The accuracy of the Content should not be relied upon and should be independently verified with primary sources of information. Taylor and Francis shall not be liable for any losses, actions, claims, proceedings, demands, costs, expenses, damages, and other liabilities whatsoever or howsoever caused arising directly or indirectly in connection with, in relation to or arising out of the use of the Content.

This article may be used for research, teaching, and private study purposes. Any substantial or systematic reproduction, redistribution, reselling, loan, sub-licensing, systematic supply, or distribution in any form to anyone is 


\title{
THE SCOTTISH
}

\section{GEOGR A P H I CAL}

\section{MAGAZINE.}

\section{ADDRESS TO THE GEOGRAPHICAL SECTION OF THE BRITISH ASSOCIATION, 1899.}

\author{
By Sir John Murray, K.C.B., F.R.S., D.Sc., LL.D., \\ President of the Section.
}

(With a Map.)

IN his opening address to the members of the British Association, at the Ipswich meeting, the President cast a retrospective glance at the progress that had taken place in the several branches of scientific inquiry from the time of the formation of the Association in 1831 down to 1895 , the year in which were published the last two of the fifty volumes of Reports containing the Scientific Results of the Voyage of H.M.S. Challenger. In that very able and detailed review there is no reference whatever to the work of the numerous expeditions which had been fitted out by this and other countries for the exploration of the depths of the sea, nor is there any mention of the great advance in our knowledge of the ocean during the period of sixty-five years then under consideration. This omission may be accounted for by the fact that, at the time of the formation of the British Association, knowledge concerning the ocean was, literally speaking, superficial. The study of marine phenomena had hitherto been almost entirely limited to the surface and shallow waters of the ocean, to the survey of coasts and of oceanic routes directly useful for commercial purposes. Down to that time there had been no systematic attempts to ascertain the physical and biological conditions of those regions of the earth's surface covered by the deeper waters of the ocean; indeed, most of the apparatus necessary for such investigations had not yet been invented.

The difficulties connected with the exploration of the greater depths of the sea arise principally from the fact that, in the majority of cases, the observations are necessarily indirect. At the surface of the ocean voL. $\mathrm{XV}$. 
direct observation is possible, but our knowledge of the conditions prevailing in deep water, and of all that is there taking place, is almost wholly dependent on the correct working of instruments, the action of which at the critical moment is hidden from sight.

It was the desire to establish telegraphic communication between Europe and America that gave the first direct impulse to the scientific exploration of the great ocean-basins, and at the present day the survey of new cable routes still yields each year a large amount of accurate knowledge regarding the floor of the ocean. Immediately before the Challenger Expedition there was a marked improvement in all the apparatus used in marine investigations, and thus during the Challenger Expedition the great ocean-basins were for the first time systematically and successfully explored. This expedition, which lasted for nearly four years, was successful beyond the expectations of its promoters, and opened out a new era in the study of oceanography. A great many sciences were enriched by a grand accumulation of new facts. Large collections were sent and brought home, and were subsequently described by specialists belonging to almost every civilised nation. Since the Challenger Expedition there has been almost a revolution in the methods employed in deep-sea observations. The most profound abysses of the ocean are now being everywhere examined by sailors and scientific men with increasing precision, rapidity, and success.

The recognition of oceanography as a distinct branch of science may be said to date from the commencement of the Challenger investigations. The fuller knowledge we now possess about all oceanic phenomena has had a great modifying influence on many general conceptions as to the nature and extent of those changes which the crust of the earth is now undergoing and has undergone in past geological times. Our knowledge of the ocean is still very incomplete. So much has, however, already been acquired that the historian will, in all probability, point to the oceanographical discoveries during the past forty years as the most important addition to the natural knowledge of our planet since the great geographical voyages associated with the names of Columbus, Da Gama, and Magellan, at the end of the fifteenth and the beginning of the sixteenth centuries.

It is not my intention on this occasion to attempt anything like a general review of the present state of oceanographic science. But, as nearly all the samples of marine deposits collected during the past thirty years have passed through my hands, I shall endeavour briefly to point out what, in general, their detailed examination teaches with respect to the present condition of the floor of the ocean, and I will thereafter indicate what appears to me to be the bearing of some of these results on speculations as to the evolution of the existing surface features of our planet.

\section{Depth of the Ochan.}

All measurements of depth, by which we ascertain the relief of that part of the earth's crust covered by water, are referred to the sea-surface; 
the measurements of height on the land are likewise referred to sea-level. It is admitted that the ocean has a very complicated undulating surface, in consequence of the attraction which the heterogeneous and elevated portions of the lithosphere exercise on the liquid hydrosphere. In the opinion of geodesists the geoid may in some places depart from the figure of the spheroid by 1000 feet. Still it is not likely that this surface of the geoid departs so widely from the mean ellipsoidal form as to introduce a great error into our estimates of the elevations and depressions on the surface of the lithosphere.

The soundings over the water-surface of the globe have accumulated at a rapid rate during the past fifty years. In the shallow water, where it is necessary to know the depth for purposes of navigation, the soundings may now be spoken of as innumerable; the 100 -fathom line surrounding the land can therefore often be drawn in with much exactness. Compared with this shallow-water region, the soundings in deep water beyond the 100 -fathom line are much less numerous; each year, however, there are large additions to our knowledge. Within the last decade over ten thousand deep soundings have been taken by British ships alone. The deep soundings are scattered over the different ocean-basins in varying proportions, being now most numerous in the North Atlantic and South-west Pacific, and in these two regions the contour-lines of depth may be drawn in with greater confidence than in the other divisions of the great ocean-basins. It may be pointed out that 659 soundings taken quite recently during cable surveys in the North Atlantic, although much closer together than is usually the case, and yielding much detailed information to cable engineers, have, from a general point of view, necessitated but little alteration in the contour-lines drawn on the Challenger bathymetrical maps published in 1895. Again, the recent soundings of the German s.s. Valdivia in the Atlantic, Indian, and Southern Oceans have not caused very great alteration in the positions of the contourlines on the Challenger maps, if we except one occasion in the South Atlantic when a depth of 2000 fathoms was expected and the sounding-machine recorded a depth of only 536 fathoms, and again in the great Southern Ocean when depths exceeding 3000 fathoms were obtained in a region where the contour-lines indicated between 1000 and 2000 fathoms. This latter discovery suggests that the great depth recorded by Ross to the south-east of South Georgia may not be very far from the truth.

I have redrawn the several contour-lines of depth in the great oceanbasins, after careful consideration of the most recent data, and these may now be regarded as a somewhat close approximation to the actual state of matters, with the possible exception of the great Southern and Antarctic Oceans, where there are relatively few soundings, but where the projected Antarctic Expeditions should soon be at work. On the whole it may be said that the general tendency of recent soundings is to extend the area with depths greater than 1000 fathoms and to show that numerous volcanic cones rise from the general level of the floor of the ocean-basins up to various levels beneath the sea-surface. 
The areas marked out by the contour-lines of depth are now estimated as follows :-

Between the shore and 100 fms., 7,000,000 sq. geo.m. (or $7 \%$ of the sea-bed)

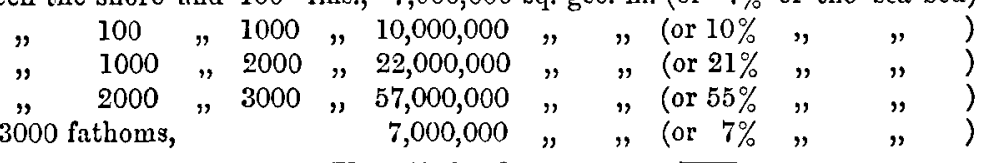

Over 3000 fathoms,

$$
\text { 103,000,000 sq. geo. m. } \overline{100} \text { per cent. }
$$

From these results it appears that considerably more than half of the sea-floor lies at a depth exceeding 2000 fathoms, or over two geographical miles. It is interesting to note that the area within the 100 -fathom line occupies $7,000,000$ square geographical miles, whereas the area occupied by the next succeeding 900 fathoms (viz., between 100 and 1000 fathoms) occupies only 10,000,000 square geographical miles. This points to a relatively rapid descent of the sea-floor along the continental slopes between 100 and 1000 fathoms, and therefore confirms the results gained by actual soundings in this region, many of which indicate steep inclines or even perpendicular cliffs. Not only are the continental slopes the seat of many deposit-slips and seismic disturbances, but Mr. Benest has given good reasons for believing that underground rivers sometimes enter the sea at depths beyond 100 fathoms, and there bring about sudden changes in deep water. Again, the relatively large area covered by the continental shelf between the shore-line and 100 fathoms points to the wearing away of the land by current and wave action.

On the Challenger charts all areas where the depth exceeds 3000 fathoms have been called "Deeps," and distinctive names have been conferred upon them. Forty-three such depressions are now known, and the positions of these are shown on the map here exhibited; twentyfour are situated in the Pacific Ocean, three in the Indian Ocean, fifteen in the Atlantic Ocean, and one in the Southern and Antarctic Oceans. The area occupied by these forty-three deeps is estimated at 7,152,000 square geographical miles, or about 7 per cent. of the total watersurface of the globe. Within these deeps over 250 soundings have been recorded, of which twenty-four exceed 4000 fathoms, including three exceeding 5000 fathoms.

Depths exceeding 4000 fathoms (or four geographical miles) have been recorded within eight of the deeps, viz., in the North Atlantic within the Nares Deep; in the Antarctic within the Ross Deep; in the Banda Sea within the Weber Deep; in the North Pacific within the Challenger, Tuscarora and Supan Deeps; and in the South Pacific within the Aldrich and Richards Deeps. Depths exceeding 5000 fathoms have been hitherto recorded only within the Aldrich Deep of the South Pacific, to the east of the Kermadecs and Friendly Islands, where the greatest depth is 5155 fathoms, or 530 feet more than five geographical miles, being about 2000 feet more below the level of the sea than the summit of Mount Everest in the Himalayas is above it. The levels on the surface of the lithosphere thus oscillate between the limits of about ten gejgraphical miles (more than eighteen kilometres). 


\section{Temperature of the Ocean Flook.}

Our knowledge of the temperature on the floor of the ocean is derived from observations in the layers of water immediately above the bottom by means of deep-sea thermometers, from the electric resistance of telegraph cables resting on the bed of the great ocean-basins, and from the temperature of large masses of mud and ooze brought up by the dredge from great depths. These observations are now sufficiently numerous to permit of some general statements as to the distribution of temperature over the bottom of the great oceans.

All the temperatures recorded up to the present time in the subsurface waters of the open ocean indicate that at a depth of about 100 fathoms seasonal variation of temperature disappears. Beyond that depth there is a constant, or nearly constant, temperature at any one place throughout the year. In some special positions, and under some peculiar conditions, a lateral shifting of large bodies of water takes place on the floor of the ocean at depths greater than 100 fathoms. This phenomenon has been well illustrated by Professor Libbey off the east coast of North America, where the Gulf Stream and Labrador Current run side by side in opposite directions. This lateral shifting cannot, however, be called seasonal, for it appears to be effected by violent storms, or strong off-shore winds bringing up colder water from considerable depths to supply the place of the surface drift, so that the colder water covers stretches of the ocean's bed which under normal conditions are overlaid by warmer strata of water. Sudden changes of temperature like these cause the destruction of innumerable marine animals, and produce very marked peculiarities in the deposits over the areas thus affected.

It is estimated that 92 per cent. of the entire sea-floor has a temperature lower than $40^{\circ} \mathrm{F}$. This is in striking contrast to the temperature prevailing at the surface of the ocean, only 16 per cent. of which has a mean temperature under $40^{\circ} \mathrm{F}$. The temperature over nearly the whole of the floor of the Indian Ocean in deep water is under $35^{\circ} \mathrm{F}$. A similar temperature occurs over a large part of the South Atlantic and certain parts of the Pacific, but at the bottom of the North Atlantic basin and over a very large portion of the Pacific the temperature is higher than $35^{\circ} \mathrm{F}$. In depths beyond 2000 fathoms, the average temperature over the floor of the North Atlantic is about $2^{\circ} \mathrm{F}$. above the average temperature at the bottom of the Indian Ocean and South Atlantic, while the average temperature of the bed of the Pacific is intermediate between these.

It is admitted that the low temperature of the deep sea has been acquired at the surface in Polar and sub-Polar regions, chiefly within the higher latitudes of the southern hemisphere, where the cooled surface-water sinks to the bottom and spreads slowly over the floor of the ocean into equatorial regions. These cold waters carry. with them into the deep sea the gases of the atmosphere, which are everywhere taken up at the surface according to the known laws of gas absorption. In this way myriads of living animals are enabled to carry on their existence at all depths in the open ocean. The nitrogen remains more or 
less constant at all times and places, but the proportion of oxygen is frequently much reduced in deep water, owing to the processes of oxidation and respiration which are there going on.

The deep sea is a region of darkness as well as of low temperature, for the direct rays of the sun are wholly absorbed in passing through the superficial layers of water. Plant-life is in consequence quite absent over 93 per cent. of the bottom of the ocean, or 66 per cent. of the whole surface of the lithosphere. The abundant deep-sea fauna, which covers the floor of the ocean, is therefore ultimately dependent for food upon organic matter assimilated by plants near its surface, in the shallower waters near the coast-lines, and on the surface of the dry land itself.

As has been already stated, about 7,000,000 square geographical miles of the sea-floor lie within the 100-fathom line, and this area is in consequence subject to seasonal variations of temperature, to strong currents, to the effects of sunlight, and presents a great variety of physical conditions. The planktonic plant-life is here reinforced by the littoral seaweeds, and animal-life is very abundant. About 40 per cent. of the water over the bottom of this shallow-water area has a mean temperature under $40^{\circ} \mathrm{F}$., while 20 per cent. has a mean temperature between $40^{\circ}$ and $60^{\circ} \mathrm{F}$., and 40 per cent. a temperature of over $60^{\circ} \mathrm{F}$.

It follows from this that only 3 per cent. of the floor of the ocean presents conditions of temperature favourable for the vigorous growth of corals and those other benthonic organisms which make up coral reefs and require a temperature of over $60^{\circ} \mathrm{F}$. all the year round. On the other hand, more than half of the surface of the ocean has a temperature which never falls below $60^{\circ} \mathrm{F}$. at any time of the year. In these surface-waters with a high temperature, the shells of pelagic Molluscs, Foraminifera, Algæ, and other planktonic organisms are secreted in great abundance, and fall to the bottom after death.

It thus happens that, at the present time, over nearly the whole floor of the ocean we have mingled in the deposits the remains of organisms which had lived under widely different physical conditions, since the remains of organisms which lived in tropical sunlight, and in water at a temperature above $80^{\circ} \mathrm{F}$, all their lives, now lie buried in the same deposit on the sea-floor together with the remains of other organisms which lived all their lives in darkness and at a temperature near to the freezing-point of fresh water.

\section{Marine Deposits on the Ocean Floor.}

The marine deposits now forming over the floor of the ocean present many interesting peculiarities according to their geographical and bathymetrical position. On the continental shelf, within the 100-fathom line, sands and gravels predominate, while on the continental slopes beyond the 100-fathom line, Blue Muds, Green Muds, and Red Muds, together with Volcanic Muds and Coral Muds, prevail, the two latter kinds of deposits being, however, more characteristic of the shallow water around oceanic islands. The composition of all these Terrigenous Deposits depends on the structure of the adjoining land. Around 
continental shores, except where coral reefs, limestones, and volcanic rocks are present, the materials consist principally of fragments and minerals derived from the disintegration of the ancient rocks of the continents, the most characteristic and abundant mineral species being quartz. River detritus extends in many instances far from the land, while off high and bold coasts, where no large rivers enter the sea, pelagic conditions may be found in somewhat close proximity to the shore-line. It is in these latter positions that Green Muds containing much glauconite, and other deposits containing many phosphatic nodules, have for themost part been found, as, for instance, off the eastern coast of the United States, off the Cape of Good Hope, and off the eastern coasts of Australia and Japan. The presence of glauconitic grains and phosphatic nodules in the deposit at these places appears to be very intimately associated with a great annual range of temperature in the surface and shallow waters, and the consequent destruction of myriads of marine animals. As an example of this phenomenon may be mentioned the destruction of the tile-fish in the spring of 1882 off the eastern coast of North America, when a layer six feet in thickness of dead fish and other marine animals was believed to cover the ocean-floor for many square miles.

In all the Terrigenous Deposits the evidences of the mechanical action of tides, of currents, and of a great variety of physical conditions, may almost everywhere be detected, and it is possible to recognise in these deposits an accumulation of materials analogous to many of the marine stratified rocks of the continents, such as sandstones, quartzites, shales, marls, greensands, chalks, limestones, conglomerates, and volcanic grits.

With increasing depth and distance from the continents the deposits gradually lose their terrigenous character, the particles derived directly from the emerged land decrease in size and in number, the evidences of mechanical action disappear, and the deposits pass slowly into what have been called Pelagic Deposits at an average distance of about 200 miles from continental coast-lines. The materials composing Pelagic Deposits are not directly derived from the disintegration of the continents and other land-surfaces. They are largely made up of the shells and skeletons of marine organisms secreted in the surface waters of the ocean, consisting either of carbonate of lime, such as pelagic Molluscs, pelagic Foraminifera, and pelagic Algæ, or of silica, such as Diatoms and Radiolarians. The inorganic constituents of the Pelagic Deposits are for the most part derived from the attrition of floating pumice, from the disintegration of water-logged pumice, from showers of volcanic ashes, and from the debris ejected from submarine volcanoes, together with the products of their decomposition. Quartz particles, which play so important a rôle in the Terrigenous Deposits, are almost wholly absent, except where the surface-waters of the ocean are affected by floating ice, or where the prevailing winds have driven the desert sands far into the oceanic areas. Glauconite is likewise absent from these abysmal regions. The various kinds of Pelagic Deposits are named according to their characteristic constituents, Pteropod Oozes, Globigerina Oozes, Diatom Oozes, Radiolarian Oozes, and Red Clay. 
The distribution of the deep-sen deposits over the floor of the ocean is shown on the map here exhibited, but it must be remembered that there is no sharp line of demarcation between them; the Terrigenous pass gradually into the Pelagic Deposits, and the varieties of each of these great divisions also pass insensibly the one into the other, so that it is often difficult to fix the name of a given sample.

On another map here exhibited the percentage distribution of carbonate of lime in the deposits over the floor of the ocean has been represented, the results being founded on an extremely large number of analyses. The results are also shown in the following table:-

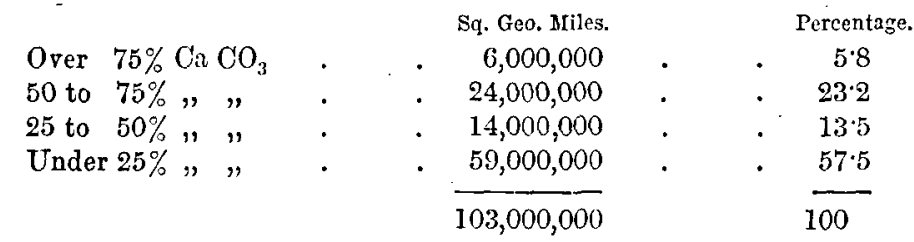

The carbonate of lime shells derived from the surface play a great and puzzling rôle in all deep-sea deposits, varying in abundance according to the depth of the ocean and the temperature of the surface-waters. In tropical regions removed from land, where the depths are less than 600 fathoms, the carbonate of lime due to the remains of these organisms from the surface may rise to 80 or 90 per cent.; with increase of depth, and under the same surface conditions, the percentage of carbonate of lime slowly diminishes, till, at depths of about 2000 fathoms, the average percentage falls to about 60 , at 2400 fathoms to about 30 , and at about 2600 fathoms to about 10, beyond which depth there may be only traces of carbonate of lime due to the presence of surface-shells. The thin and more delicate surface-shells first disappear from the deposits, the thicker and denser ones alone persist to greater depths. A careful examination of a large number of observations shows that the percentage of carbonate of lime in the deposits falls off much more rapidly at depths between 2200 and 2500 fathoms than at other depths.

The Red Clay, which occurs in all the deeper stretches of the ocean firr from land, and covers nearly half of the whole sea-floor, containsin addition to volcanic débris, clayey matter, the oxides of iron and manganese-numerous remains of whales, sharks, and other fishes, together with zeolitic crystals, manganese nodules, and minute magnetic spherules, which are believed to have a cosmic origin. One haul of a small trawl in the Central Pacific brought to the surface on one occasion, from a depth of about two and a half miles, many bushels of manganese nodules, along with fifteen hundred sharks' teeth, over fifty fragments of earbones and other bones of whales. Some of these organic remains, such as the Carcharodon and Lamna teeth and the bones of the Ziphioid whales belong apparently to extinct species. One or two of these sharks' teeth, earbones, or cosmic spherules, may be occasionally found in a Globigerina Ooze, but their occurrence in this or any deposits other than Red Clay is extremely rare.

Our knowledge of the marine deposits is limited to the superficial 
layers; as a rule the sounding-tube does not penetrate more than six or eight inches, but in some positions the sounding-tube and dredge have been known to sink fully two feet into the deposit. Sometimes a Red Clay is overlaid by a Globigerina Ooze, more frequently a Red Clay overlies a Globigerina Ooze, the transition between the two layers being either abrupt or gradual. In some positions it is possible to account for these layers by referring them to changes in the condition of the surface-waters, but in other situations it seems necessary to call in elevations and subsidences of the sea-floor.

If the whole of the carbonate of lime shells be removed by dilute acid from a typical sample of Globigerina Ooze, the inorganic residue left behind is quite similar in composition to a typical Red Clay. This suggests that possibly, owing to some hypogene action, such as the escape of carbonic acid through the sea-floor, a deposit that once was a Globigerina Ooze might be slowly converted into a Red Clay. However, this is not the interpretation which commends itself after an examination of all the data at present available; a consideration of the rate of accumulation probably affords a more correct interpretation. It appears certain that the Terrigenous Deposits accumulate much more rapidly than the Pelagic Deposits. Among the Pelagic Deposits the Pteropod and Globigerina Oozes of the tropical regions, being made up of the calcareous shells of a much larger number of tropical species, apparently accumulate at a greater rate than the Globigerina Oozes in extra-tropical areas. Diatom Ooze being composed of both calcareous and siliceous organisms has again a more rapid rate of deposition than Radiolarian Ooze. In Red Clay the minimum rate of accumulation takes place. The number of sharks' teeth, of earbones and other bones of Cetaceans, and of cosmic spherules, in a deposit may indeed be taken as a measure of the rate of deposition. These spherules, teeth, and bones are probably more abundant in the Red Clays, because few other substances there fall to the bottom to cover them up, and they thus form an appreciable part of the whole deposit. The volcanic materials in a Red Clay having, because of the slow accumulation, been for a long time exposed to the action of sen-water, have been profoundly altered. The massive manganese-iron nodules and zeolitic crystals present in the deposit are secondary products arising from the decomposition of these volcanic materials, just as the formation of glauconite, phosphatic, and calcareous and barytic nodules accompanies the decomposition of terrigenous rocks and minerals in deposits nearer continental shores. There is thus a striking difference between the average chemical and mineralogical composition of Terrigenous and Pelagic Deposits.

It would be extremely interesting to have a detailed examination of one of those deep holes where a typical Red Clay is present, and even to bore some depth into such a deposit if possible, for in these positions it is probable that not more than a few feet of deposit have accumulated since the close of the Tertiary period. One such area lies to the south-west of Australia, and its examination might possibly form part of the programme of the approaching Antarctic explorations. 


\section{Life on the OCEan Floor.}

It has already been stated that plant-life is limited to the shallow waters, but fishes and members of all the invertebrate groups are distributed over the floor of the ocean at all depths. The majority of these deep-sea animals live by eating the mud, clay, or ooze, or by catching the minute particles of organic matter which fall from the surface. It is probably not far from the truth to say that three-fourths of the deposits now covering the floor of the ocean have passed through the alimentary canals of marine animals. These mud-eating species, many of which are of gigantic size when compared with their allies living in the shallow coastal waters, become in turn the prey of numerous rapacious animals armed with peculiar prehensile and tactile organs. Some fishes are blind, while others have very large eyes. Phosphorescent light plays a most important rôle in the deep sea, and is correlated with the prevailing red and brown colours of deep-sea organisms. Phosphorescent organs appear sometimes to act as a bull'seye lantern to enable particles of food to be picked up, and at other times as a lure or a warning. All these peculiar adaptations indicate that the struggle for life may be not much less severe in the deep-sea than in the shallower waters of the ocean.

Many deep-sea animals present archaic characters; still the deep sea cannot be said to contain more remnants of faunas which flourished in remote geological periods than the shallow and fresh waters of the continents. Indeed, king-crabs, Lingulas, Trigonias, Port Jackson sharks, Ceratodus, Lepidosiren, and Protopterus, probably represent older faunas than anything to be found in the deep sea.

Sir Wyville Thomson was of opinion that, from the Silurian period to the present day, there had been as now a continuous deep ocean with a bottom temperature oscillating about the freezing-point of fresh water, and that there had always been an abyssal fauna. I incline to the view that in Palæozoic times the ocean-basins were not so deep as they are now, that the ocean then had throughout a nearly uniform high temperature, and that life was either absent or represented only by bacteria and other low forms in great depths, as is now the case in the Black Sea, where life is practically absent beyond 100 fathoms, and where the deeper waters are saturated with sulphuretted hydrogen. This is not, however, the place to enter on speculations concerning the origin of the deep-sea fauna, nor to dwell on what has been called "bipolarity" in the distribution of marine organisms.

\section{Evolution of the Continental and Oceanic Areas.}

I have now pointed out what appears to me to be some of the more general results arrived at in recent years regarding the present condition of the floor of the ocean. I may now be permitted to indicate the possible bearing of these results on opinions as to the origin of some fundamental geographical phenomena, for instance, on the evolution of the protruding continents and sunken ocean-basins. In dealing with 
such a problem, much that is hypothetical must necessarily be introduced, but these speculations are based on ascertained scientific facts. The well-known American geologist, Dutton, says:- "It has been much the habit of geologists to attempt to explain the progressive elevation of plateaus and mountain platforms, and also the foldings of strata, by one and the same process. I hold the two processes to be distinct, and having no necessary relation to each other. There are plicated regions which are little or not at all elevated, and there are elevated regions which are not plicated." Speaking of great regional uplifts, he says further:- "What the real nature of the uplifting force may be is, to my mind, an entire mystery, but I think we may discern at least one of its attributes, and that is a gradual expansion or a diminution of density of the subterranean magmas. ... We know of no cause which could either add to the mass or diminish the density, yet one of the two must surely have happened. . . . Hence I infer that the cause which elevates the land involves an expansion of the underlying magmas, and the cause which depresses it is a shrinkage of the magmas: the nature of the process is at present a complete mystery." I shall endeavour to show how the detailed study of marine deposits may help to solve the mystery here referred to by Dutton.

The surface of the globe has not always been as we now see it. When, in the past, the surface had a temperature of about $400^{\circ} \mathrm{F}$., what is now the water of the ocean must have existed as water vapour in the atmosphere, which would thereby-as well as because of the presence of other substances-be increased in density and volume. Life, as we know it, could not then exist. Again, science foresees a time when low temperatures, like those produced by Professor Dewar at the Royal Institution, will prevail over the face of the earth. The hydrosphere and atmosphere will then have disappeared within the rocky crust, or the waters of the ocean will have become solid rock, and over their surface will roll an ocean of liquid air, about 40 feet in depth. Life, as we know it, unless it undergoes suitable secular modifications, will be extinct. Somewhere between these two indefinite points of time in the evolution of our planet it is our privilege to live, to investigate, and to speculate concerning the antecedent and future conditions of things.

When we resard our globe with the mind's eye, it appears at the present time to be formed of concentric spheres, very like, and still very unlike, the successive coats of an onion. Within is situated the vast nucleus or centrosphere; surrounding this is what may be called the tektosphere, ${ }^{1}$ a shell of materials in a state bordering on fusion, upon which rests and creeps the lithosphere. Then follow hydrosphere and atmosphere, with the included biosphere. ${ }^{2}$ To the interaction of these six geospheres, through energy derived from internal and external sources, may be referred all the existing superficial phenomena of the planet.

The vast interior of the planetary mass, although not under direct observation, is known, from the results of the astronomer and physicist, to have a mean density of $5 \cdot 6$, or twice that of ordinary surface rock. 
The substances brought within the reach of observation in veinstones, in lavas, and hypogene rocks-by the action of water as a solvent and sublimant-warrant the belief that the centrosphere is largely made up of metals and metalloids with imprisoned gases. It is admitted that the vast nucleus has a very high temperature, but so enormous is the pressure of the superincumbent crust, that the melting-point of the substances in the interior is believed to be raised to a higher value than the temperature there existing-the centrosphere in consequence remains solid, for it may be assumed that the melting-point of rock-forming materials is raised by increase of pressure. Astronomers from a study of precession and nutation have long been convinced that the centrosphere must be practically solid.

Recent seismological observations indicate the transmission of two types of waves through the earth-the condensational-rarefactional, and the purely distortional-and the study of these tremors supports the view that the centrosphere is not only solid but possesses great uniformity of structure. The seismological investigations of Professors Milne and Knott point also to a fairly abrupt boundary or transition surface, where the solid nucleus passes into the somewhat plastic magma on which the firm upper crust rests.

In this plastic layer or shell-named the tektosphere-the materials are most probably in a state of unstable equilibrium and bordering on fusion. Here, the loose-textured solids of the external crust are converted into the denser solids of the nucleus or into molten masses, at a critical point of temperature and pressure; deep-seated rocks may in consequence escape through fissures in the lithosphere. Within the lithosphere itself the temperature falls off so rapidly towards the surface as to be everywhere below the melting-point of any substance there under its particular pressure.

Now, as the solid centrosphere slowly contracted from loss of heat, the primitive lithosphere, in accommodating itself-through changes in the tektosphere-to the shrinking nucleus, would be buckled, warped, and thrown into ridges. That these movements are still going on is shown by the fact that the lithosphere is everywhere and at all times in a slight but measurable state of pulsation. The rigidity of the primitive rocky crust would permit of considerable deformations of the kind here indicated. Indeed, the compression of mountain chains has most probably been brought about in this manner, but the same cannot be said of the elevation of plateaus, of mountain platforms, and of continents.

From many lines of investigation it is concluded, as we have seen, that the centrosphere is homogeneous in structure. Direct observation, on the other hand, shows that the lithosphere is heterogeneous in composition. How has this heterogeneity been brought about? The original crust was almost certainly composed of complex and stable silicates, all the silicon dioxide being in combination with bases. Lord Kelvin has pointed out that, when the solid crust began to form, it would rapidly cool over its whole surface; the precipitation of water would accelerate this process, and there would soon be an approximation to present con= ditions. As time went on the plastic or critical layer-the tektosphere 
-immediately beneath the crust would gradually sink deeper and deeper, while ruptures and re-adjustments would become less and less frequent than in earlier stages. With the first fall of rain the silicates of the crust would be attacked by water and carbon dioxide, which can at low temperatures displace silicon dioxide from its combinations. The silicates in consequence have been continuously robbed of a part, or the whole, of their bases. The silica thus set free goes ultimately to form quartz veins and quartz sand on or about the emerged land, while the bases leached out of the disintegrating rocks are carried out into the ocean and ocean-basins. A continuous disintegration and differentiation of materials of the lithosphere, accompanied by a sort of migration and selection among mineral substances is thus always in progress. Through the agency of life, carbonate of lime accumulates in one place; through the agency of winds, quartz sand is heaped up in another; through the agency of water, beds of clay, of oxides of iron and of manganese are spread out in other directions.

The contraction of the centrosphere supplies the force which folds and crumples the lithosphere. The combined effect of hydrosphere, atmosphere, and biosphere on the lithosphere gives direction and a determinate mode of action to that force. From the earliest geological times the most resistant dust of the continents has been strewn along the marginal belt of the sea-floor skirting the land. At the present time the deposits over this area contain on the average about 70 per cent. of free and combined silica, most of this being in the form of quartz sand. In the abysmal deposits far from land there is an average of only about 30 per cent of silica, and hardly any of this in the form of quartz sand. Lime, iron, and the other bases largely predominate in these abysmal regions. The continuous loading on the margins of the emerged land by deposits tends by increased pressure to keep the materials of the tektosphere in a solid condition immediately beneath the loaded area. The unloading of emerged land tends by relief of pressure to produce a viscous condition of the tektosphere immediately beneath the denuded surfaces. Under the influence of the continuous shalkings, tremors, and tremblings always taking place in the lithosphere the materials of the tektosphere yield to the stresses acting on them, and the deep-seated portions of the terrigenous deposits are slowly carried towards, over, or underneath the emerged land. The rocks subsequently re-formed beneath continental areas out of these terrigenous materials, under great pressure and in hydrothermal conditions, would be more acid than the rocks from which they were originally derived, and it is well known that acid rocks have a less specific gravity than intermediate or basic ones. By a continual repetition of this process the continental protuberances have been gradually built up of lighter materials than the other parts of the lithosphere. The relatively light quartz, which is also the most refractory, the most stable, and the least fusible among rock-forming minerals, plays in all this the principal role. The average height of the surface of the continents is about three miles above the average level of the abysmal regions. If now we assume the average density of the crust beneath the continents to be $2 \cdot 5$, and of the part beneath the abysmal regions to be 3 , 
then the spheroidal surface of equal pressure-the tektosphere-would have a minimum depth of eighteen miles beneath the continents and fifteen miles beneath the oceans, or, if we assume the density of the crust beneath the continents to be $2 \cdot 5$ and beneath the abysmal regions to be $2 \cdot 8$, then the tektosphere would be twenty-eight miles beneath the continents and twenty-five miles beneath the oceans. The present condition of the earth's crust might be brought about by the disintegration of a quantity of quartz-free volcanic rock, covering the continental areas to a depth of eighteen miles, and the re-formation of rocks out of the disintegrated materials.

Where the lighter and more bulky substances have accumulated there has been a relative increase of volume, and in consequence bulging has taken place at the surface over the continental areas. Where the denser materials have been laid down there has been flattening, and in consequence a depression of the abysmal regions of the ocean-basins. It is known that, as a general rule, where large masses of sediment have been deposited, their deposition has been accompanied by a depression of the area. On the other hand, where broad mountain platforms have been subjected to extensive erosion, the loss of altitude by denudation has been made good by a rise of the platform. This points to a movement of matter on to the continental areas.

If this be anything like a true conception of the interactions that are taking place between the various geospheres of which our globe is made up, then we can understand why, in the gradual evolution of the surface features, the average level of the continental plains now stands permanently about three miles above the average level of those plains which form the floor of the deep ocean-basins. We may also understand how the defect of mass under the continents and an excess of mass under the oceans have been brought about, as well as deficiency of mass under mountains and excess of mass under plains. Even the local anomalies indicated by the plumb-line, gravity, and magnetic observations may in this way receive a rational explanation. It has been urged that an enormous time-greater even than what is demanded by Darwinwould be necessary for an evolution of the existing surface features on these lines. I do not think so. Indeed, in all that relates to geological time I agree, generally speaking, with the physicists rather than with the biologists and geologists.

\section{Progress of Oceanic Research.}

I have now touched on some of the problems and speculations suggested by recent deep-sea explorations, and there are many others, equally attractive, to which no reference has been made. It is abundantly evident that, for the satisfactory explanation of many marine phenomena, further observations and explorations are necessary. Happily there is no sign that the interest in oceanographical work has in any way slackened. On the contrary, the number of scientific men and ships engaged in the study of the ocean is rapidly increasing. Among all civilised peoples and in all quarters of the globe the economic 
importance of many of the problems that await solution is clearly recognised.

We have every reason to be proud of the work continually carried on by the officers and ships attached to the Hydrographic Department of the British Navy. They have surveyed coasts in all parts of the world for the purposes of navigation, and within the past few years have greatly enlarged our knowledge of the sea-bed and deeper waters over wide stretches of the Pacific and other oceans. The samples of the bottom which are procured, being always carefully preserved by the officers, have enabled very definite notions to be formed as to the geographical and bathymetrical distribution of marine deposits.

The ships belonging to the various British Telegraph Cable Companies have done most excellent work in this as well as in other directions. Even during the present year, Mr. R. E. Peake has in the s.s. Britannia procured 477 deep soundings in the North Atlantic, besides a large collection of deep-sea deposits, and many deep-sea temperature and current observations.

The French have been extending the valuable work of the Talisman and Travailleur, while the Prince of Monaco is at the present moment carrying on his oceanic investigations in the Arctic Seas with a large new yacht elaborately and specially fitted out for such work. The Russians have recently been engaged in the scientific exploration of the Black Sea and the Caspian Sea, and a special ship is now employed in the investigation of the Arctic fisheries of the Murman coast under the direction of Professor Knipowitsch. Admiral Makaroff has this summer been hammering his way through Arctic ice, and at the same time carrying on a great variety of systematic observations and experiments on board the Yermak-the most powerful and most effective instrument of marine research ever constructed. Mr. Alexander Agassiz has this year recommenced his deep-sea explorations in the Pacific on board the U.S. steamer Albatross. He proposes to cross the Pacific in several directions, and to conduct investigations among the Paumotu and other coral island groups. Professor Weber is similarly employed on board a Dutch man-ofwar in the East Indian Seas. The Deutsche Seewarte at Hamburg, under the direction of Dr. Neumayer, continues its praiseworthy assistance and encouragement to all investigators of the ocean, and this year the important German Deep-sea Expedition, in the s.s. Valdivia, arrived home after most successful oceanographical explorations in the Atlantic, Indian, and Great Southern Oceans.

The Belgica has returned to Europe safely with a wealth of geological and biological collections and physical observations, after spending, for the first time on record, a whole winter among the icefields and icebergs of the Antarctic. Mr. Borchgrevink in December last again penetrated to Cape Adare, successfully landed his party at that point, and is now wintering on the Antarctic continent. The expeditions of Lieutenant Peary, of Professor Nathorst, of Captain Sverdrup, and of the Duke of Abruzzi, which are now in progress, may be expected to yield much new information about the condition of the Arctic Ocean. Mr. Wellman 
has just returned from the north of Franz Josef Land with observations of considerable interest.

Some of the scientific results obtained by the expeditions in the Danish steamer Ingolf have lately been published, and these, along with the results of the joint work pursued for many years by the Swedes, Danes, and Norwegians, may ultimately have great economic value from their direct bearing on Fishery problems, and on weather forecasting over long periods of time.

Largely through the influence of Professor Otto Pettersson an International Conference assembled at Stockholm a few months ago, for the purpose of deliberating as to a programme of conjoint scientific work in the North Sea and northerm parts of the Atlantic, with special reference to the economic aspect of sea-fisheries. A programme was successfully drawn up, and an organisation suggested for carrying it into effect; these proposals are now under the consideration of the several states. The Norwegian Government has voted a large sum of money for building a special vessel to conduct marine investigations of the nature recommended by this conference. It is to be hoped the other North Sea Powers may soon follow this excellent example.

The various marine stations and laboratories for scientific research in all parts of the world furnish each year much new knowledge concerning the ocean. Among our own people the excellent work carried on by the Marine Biological Association, the Irish Fisheries Department, the Scottish Fishery Board, the Lancashire Fisheries Committee, the Cape and Canadian Fisheries Departments, is well worthy of recognition and continued support. Mr. George Murray, Mr. H. N. Dickson, Professor Cleve, Professor Otto Pettersson, Mr. Robert Irvine, and others, have, with the assistance of the officers of the Mercantile Marine, accumulated in recent years a vast amount of information regarding the distribution of temperature and salinity, as well as of the planktonic organisms at the surface of the ocean. The papers by Mr. H. C. Russell on the icebergs and currents of the Great Southern Ocean, and of Mr. F. W. Walker on the density of the water in the Southern Hemisphere, show that the Australian colonies are taking a practical interest in oceanographical problems.

\section{Proposed Antarctic Explonations.}

The great event of the year, from a geographical point of view, is the progress that has been made towards the realisation of a scheme for the thorough scientific exploration in the near future of the whole South Polar region. The British and German Governments have voted or guaranteed large sums of money to assist in promoting this object, and princely donations have likewise been received from private individualsin this connection the action of Mr. L. W. Longstaff in making a gift of $£ 25,000$, and of Mr. A. C. Harmsworth in promising $£ 5000$, being beyond all praise.

There is an earnest desire among the scientific men of Britain and Germany that there should be some sort of co-operation with regard to 
the scientific work of the two expeditions, and that these should both sail in 1901, so that the invaluable gain attaching to simultaneous observations may be secured. Beyond this nothing has, as yet, been definitely settled. The members of the Association will presently have an opportunity of expressing their opinions as to what should be attempted by the British Expedition, how the work in connection with it should be arranged, and how the various researches in view can best be carried to a successful issue.

I have long taken a deep interest in Antarctic exploration, because such exploration must necessarily deal largely with oceanographical problems, and also because I have had the privilege of studying the conditions of the ocean within both the Arctic and Antarctic circles. In the year 1886 I published an article on the subject of Antarctic Exploration in the Scottish Geographical Magazine. This article led to an interesting interview, especially when viewed in the light of after-events, for, a few weeks after it appeared in type, a young Norwegian walked into the Challenger Office in Edinburgh to ask when the proposed expedition would probably start, and if there were any chance of his services being accepted. His name was Nansen.

When at the request of the President I addressed the Royal Geographical Society on the same subject in the year 1893, I made the following statement as to what it seemed to me should be the general character of the proposed exploration: "A dash at the South Pole is not, however, what I advocate, nor do I believe that is what British Science at the present time desires. It demands rather a steady, continuous, laborious, and systematic exploration of the whole southern region with all the appliances of the modern investigator." At the same time I urged further, that these explorations should be undertaken by the Royal Navy in two ships, and that the work should extend over two winters and three summers.

This scheme must now be abandoned, so far at least as the Royal Navy is concerned, for the Government has intimated that it can spare neither ships nor officers, men nor money, for an undertaking of such magnitude. The example of Foreign Powers-rather than the representations from our own scientific men-appears to have been chiefly instrumental in at last inducing the Government to promise a sum of $£ 45,000$, provided that an equal amount be forthcoming from other sources. This resolve throws the responsibility for the financial administration, for the equipment, and for the management of this exploration, on the representative scientific societies, which have no organisation ready for carrying out important executive work on such an extensive scale. I am doubtful whether this state of matters should be regarded as a sign of increasing lukewarmness on the part of the Government towards marine research, or should rather be looked on as a most unexpected and welcome recognition of the growing importance of science and scientific men to the affairs of the nation. Let us adopt the latter view, and accept the heavy responsibility attached thereto.

Any one who will take the trouble to read, in the Proceedings of the Royal Society of London, the account of the discussion which recently roL. XV. 
took place on "The Scientific Advantages of an Antarctic Expedition," will gather some idea of the number and wide range of the subjects which it is urged should be investigated within the Antarctic area; the proposed researches have to do with almost every branch of science. Unless an earnest attempt be made to approach very near to the ideal there sketched out, widespread and lasting disappointment will certainly be felt among the scientific men of this country. The proposed expedition should not be one of adventure. Not a rapid invasion and a sudden retreat, with tales of hardships and risks, but a scientific occupation of the unknown area by observation and experiment should be aimed at in these days.

I have all along estimated the cost of a well-equipped Antarctic Expedition at about $£ 150,000$. I see no reason for changing my views on this point at the present time, nor on the general scope of the work to be undertaken by the proposed expedition, as set forth in the papers I have published on the subject. There is now a sum of at most $£ 90,000$ in hand, or in view. If one ship should be specially built for penetrating the icy region, and be sent south with one naturalist on board, then such an expedition may, it will be granted, bring back interesting and important results. But it must be distinctly understood that this is not the kind of exploration scientific men have been urging on the British public for the past fifteen or twenty years. We must, if possible, have two ships, with landing parties for stations on shore and with a recognised scientific leader and staff on board of each ship. Although we cannot have the Royal Navy, these ships can be most efficiently officered and manned from the Mercantile Marine. With only one ship many of the proposed observations would have to be cut out of the programme. In anticipation of this being the case, there are at the present moment irreconcilable differences of opinion, among those most interested in these explorations, as to which sciences must be sacrificed.

The difficulties which at present surround this undertaking are fundamentally those of money. These difficulties would at once disappear, and others would certainly be overcome, should the members of the British Association at this meeting agree to place in the hands of

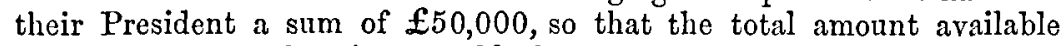
for Antarctic exploration would become something like $£ 150,000$. Although there is but one central Government, surely there are within the bounds of this great empire two more men like Mr. Longstaff. The Government has suddenly placed the burden of upholding the high traditions of Great Britain in marine research and exploration on the shoulders of her scientific men. In their name I appeal to all our well-to-do fellow-countrymen in every walk of life for assistance, so that these new duties may be discharged in a manner worthy of the empire and of the well-earned reputation of British Science. 